\title{
Geological characteristics of the nesting areas of the giant Amazon river turtle (Podocnemis expansa) in the Crixás-Açu river in Goiás State, Brazil
}

\author{
Paulo Dias FERREIRA JÚNIOR¹, Paulo de Tarso Amorim CASTRO²
}

\begin{abstract}
A large population of the giant Amazon river turtle (Podocnemis expansa) nests along the beaches of the Crixás-Açu River in the central western region of Brazil. In spite of the existence of several point bars in the area, only a selected group of beaches is used for nesting by P. expansa. Geological aspects, such as river width and depth, beach height - above $200 \mathrm{~cm}$ - with sandy sediments, were indispensable for the choice of these nesting sites. The relatively reduced dimensions of the point bars and the great number of turtles, which nest in the same local, contributed to the existence of a high nest concentration.

The rapid rise of the Crixás-Açu River caused the flooding of the beaches and the drowning of hatchlings and embryos. It is estimated that nearly all the nests were lost. The height of the nesting place and the time of flooding related to the incubation period are decisive in embryo survivorship. The Retiro, Júnior, Assombrado and Limoeiro beaches, which are situated at heights of 183 to $310 \mathrm{~cm}$, were inundated on 8 November 2000. The Barreira Branca beach, with a height of up to $380 \mathrm{~cm}$ was completely inundated on 13 December 2000. All of these beaches were flooded before the hatchlings emerged.
\end{abstract}

\section{KEY WORDS}

giant Amazon river turtle, Araguaia basin, Crixás-Açu River, nesting, Podocnemis expansa

\section{Características geológicas das áreas de nidificação da tartaruga-da- amazônia (Podocnemis expansa) no rio Crixás-Açu no Estado de Goiás, Brasil}

\begin{abstract}
RESUMO
Uma das maiores populaçôes de tartaruga-da-amazônia (Podocnemis expansa) da região Centro-Oeste do Brasil nidifica ao longo das praias do rio Crixás-Açu no estado de Goiás. Apesar de existirem inúmeras barras em pontal na área, apenas um seleto grupo de praias foi eleito como ponto de nidificação pela tartaruga-da-amazônia. Aspectos geológicos, tais como um substrato constituído por sedimentos arenosos, a presença de locais amplos e profundos no rio, e patamares elevados, acima de $200 \mathrm{~cm}$ foram imprescindiveis à escolha dos pontos de desova. As dimensóes relativamente reduzidas das barras em pontal e o grande número de individuos a desovarem no mesmo local fazem com que haja uma alta concentração de ninhos.

A rápida ascensão do nível do rio Crixás-Açu, a partir de 25 de outubro de 2000, provocou o alagamento das praias e o afogamento de filhotes e embrióes. Estima-se que quase todas os ninhos foram perdidos por este motivo. A altura do local de desova, em relação ao nivel do rio, exerceu um papel crucial sobre o momento do alagamento das praias, mas foi incapaz de assegurar a conclusão do periodo de incubação e saída dos filhotes dos ninhos. As praias do Retiro, Júnior, Assombrado e Limoeiro, situadas a uma altura que variou de 183 a $310 \mathrm{~cm}$, foram alagadas em 8 de novembro. A praia da Barreira Branca, com altura de até $380 \mathrm{~cm}$ foi completamente alagada a partir de 13 de dezembro.
\end{abstract}

\section{PALAVRAS-CHAVE}

Podocnemis expansa, tartaruga-da-amazônia, nidificação, bacia do Rio Araguaia, rio Crixás-Açu

${ }^{1}$ Centro Universitário de Vila Velha, Rua Comissário José Dantas de Melo, 21, Bairro Boa Vista, Vila Velha, ES-29.102-770. Tel.: (27) 3320-2122, e-mail: pdfj@hotmail.com 2Departamento de Geologia, Universidade Federal de Ouro Preto, Campus Morro do Cruzeiro, Ouro Preto, MG 35400-000. Tel.: (31) 3559-1600, Fax (31) 3559-1605, e-mail: paulo@degeo.ufop.br 


\section{INTRODUCTION}

The discovery that some animal species present environmental-dependent sex determination has brought to the center of discussions the importance of what physical aspects of the environment exert on the first moments of life of organisms. Charnier (1966) revealed that the Agama agama lizard's sexual determination is due to the temperature in which eggs are incubated. Pieau (1971), working with fresh water turtles from Europe - Emys orbicularis e Testudo graeca - attempted to show that turtles also possess temperature-dependent sex determination, and that it is usual that low temperatures produce males and high temperatures produce females. However this was not proven conclusively until Bull \& Vogt (1979). Temperature-dependent sex determination has now been shown to be common in turtles (Vogt \& Bull, 1982; Alho et al., 1985, Ewert et al., 2004) as well as crocodilians (Ferguson \& Joanen, 1989) and some lizards (Bragg et al., 2000, Harlow, 2004)

The giant Amazon river turtle (Podocnemis expansa) is the largest fresh water turtle in South America, widely spread over the northern and central western regions of Brazil, in the basins of Amazonas and Tocantins-Araguaia rivers (Pritchard \& Trebbau, 1984). Alho et al. (1985) have shown that the turtle has temperature-dependent sex determination and that small variations of about $1{ }^{\circ} \mathrm{C}$ in the incubation temperature are sufficient to produce significant alterations in the hatchlings sex ratio. The temperature and humidity conditions of the turtle nests are very variable and sensitive to climatic oscillations.

In the Crixás-Açu River the giant Amazon river turtle nesting sites are concentrated on sandy beaches, which appear on the riverbanks during the dry period. The nesting of the turtle in the central-western region occurs between August and October, and hatching takes place in the months of November and December. The incubation duration, according to IBAMA (1989), varies from 45 to 60 days.

Several different forms and different grain size sediments constitute the beaches nesting for nesting. The maximum height of the beaches is decisive in hatchling success for two reasons. First, the river levels change rapidly in the central and northern regions of Brazil. So, if nests are located in a low topographic position on the beaches hatchlings may drown before they emerge. Second, humidity originating from the underground water table can reduce the nest temperature or drown the embryos.

The sudden rise of the river level, called "repiquete" is the main cause for the loss of $P$. expansa, P. unifilis and $P$. sextuberculata nests in various parts of the Amazon region (Alho \& Pádua, 1982; Hildebrand et al., 1988; Mitchell \& Quiñones, 1994; Pezzuti \& Vogt, 1999; Ferreira Júnior, 2003).

Nesting of the giant Amazon river turtle occurs during the end of dry season, when sandy banks emerge close to the main fluvial channel borders. Usually they are point bars in the CrixásAçu River. The variety of beach forms, their dimensions and grain size of the sand is variable, suggesting a wide hydric and thermal environment range. However, the nesting occurs only in specific points on a small number of beaches that, apparently, are carefully chosen by the giant turtle. Therefore, when the number of turtles is too large and space is scarce, nests are concentrated. The turtle's gregarious nesting habit (Alho \& Pádua, 1982; Ernst \& Barbour, 1989, Pritchard \& Trebbau, 1984; Vanzolini, 1967) partially restricts the possible variations of the hydric and thermal environment that are acceptable hatchling survival.

In order to establish patterns of geological influence on the choice of nesting places by this turtle, several studies have been carried out in the Middle Araguaia and Crixás-Açu rivers (Ferreira Júnior, 2003, Ferreira Júnior \& Castro, 2003, 2005). The geological aspects such as geomorphology and sedimentological characteristics of these beaches have been studied. This paper analyzes the giant Amazon river turtle nesting areas in the CrixásAçu River in the state of Goiás (Brazil) during the nesting season of 2000 .

\section{MATERIALS AND METHODS}

The beaches were visited daily from August to December by the field agents working at the Centro de Conservação e Manejo de Répteis e Anfíbios do Instituto Brasileiro do Meio Ambiente e dos Recursos Naturais Renováveis (RAN/IBAMA), who marked the nests with numbered stakes. Since the concentration of the nests on the point bars was generally very high, it was impossible to locate all the nests. Therefore the IBAMA field agents estimated the number of nests based on the giant Amazon river turtle tracks and excavations found. The labeled nests were used as a reference for the measurements of the relative height of the Crixás-Açu River water level. The mapping of the beaches is on the scale of 1:1000 using compass and tape measure during October after the turtles had nested. The height of the nests and the point bars were measured with a level precise to $0.5 \mathrm{~cm}$.

On October 25, we took measurements of the height of nests and beaches. Since the Crixás-Açu River oscillated during the nesting season, the lowest level was established as a reference point. This procedure allowed the comparison among several beach heights in different places. The pluviometric data that referred to the variation of the Crixás-Açu River level were made available by the Agência Nacional de Energia Elétrica (ANEEL) and originated from the Crixás-Açu Station, situated at $49^{\circ} 57^{\prime} 05^{\prime \prime} \mathrm{W}$ and $13^{\circ} 53^{\prime} 55^{\prime \prime} \mathrm{S}$. This gauge station is located 15 $\mathrm{km}$ upstream from the Assombrado beach, which is the nearest point to the study area.

The grain size of the sediment samples collected from the beaches studied was analyzed using the grain size scale of Folk/ 
Wentworth (Folk, 1974) (Table 1). In the field, the grain size measurements were made using $10 \mathrm{x}$ magnifying lens granulometric charts.

Figure 1 shows the terminology of the geomorphologic, sedimentological and topographic features of the beaches used in our study. The length of the point bars was measured in its largest extension, parallel to the channel. The width of the point bars was the maximum width taken perpendicular to the channel.

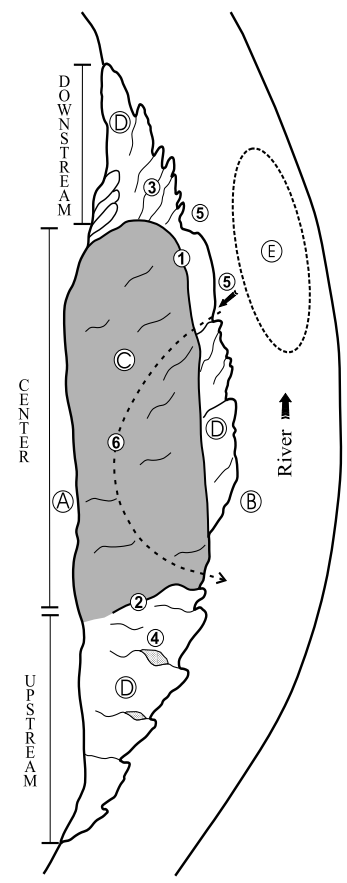

Figure 1 - Terminology used and features collected in mapping of the Javaés River point bars. A: Margin or internal part of the point bar, close to the forest. B: External margin of the point bar in contact with the river. C: The hatched part indicates the high beach points, generated by the migration and amalgamation of several sandy deposits. In this area there are dunes of small and medium size. The main nesting is by $P$. expansa. D: Low part of the beach with heights under $1.5 \mathrm{~m}$ and normally used as nesting site by the P. unifilis. E: "Boiadouro", representing the deepest points of the rivers where the turtles float and wait for the adequate moment to exit for nesting. 1: Abrupt front part constituted by the amalgamation of several large-sized dunes. This feature is named accretionary dune front by Ashworth et al. (2000). It divides the beach in two distinct topographical regions. 2: Crest of a large-sized dune. 3: Crest of a small and medium sized-dune. 4: Temporary ponds generated in front of the dunes. $\mathbf{5}$ : Trough located in front of the largesized dunes that connect the deepest points of the river to the nesting sites. They are used as access way by $P$. expansa. 6: Path covered by $P$. expansa during nesting.

\section{RESULTS}

\section{PHYSIOGRAPHIC CHARACTERISTICS OF CRIXÁS-AÇU RIVER}

The study area is a RAN/IBAMA protection and research base. There 1.700 giant Amazon river turtle females nested in only five beaches spread over $25 \mathrm{~km}$ of the Crixás-Açu River (Fig. 2) in 2000.

Besides the IBAMA field agents' protection, the turtles have a relatively well-preserved area of the Crixás-Açu River to nest in. The floodplain is characterized by several oxbow lakes. The vegetational cover is relatively well preserved on the right margin. However the left margin is more fragile, deforestation extends up to the riverbanks, with only a fragmented riparian forest remaining. The channel sinuosity is high with wide meanders but short in extension.

The Crixás-Açu River level varied $857 \mathrm{~cm}$ in 2000, with the highest level registered on 20 December, and the lowest on 25 October (Fig. 3). In 2000, during the months of June to October, the Crixás-Açu River reached its lowest level, exposing point bars (hereafter denominated beaches) that were used by the

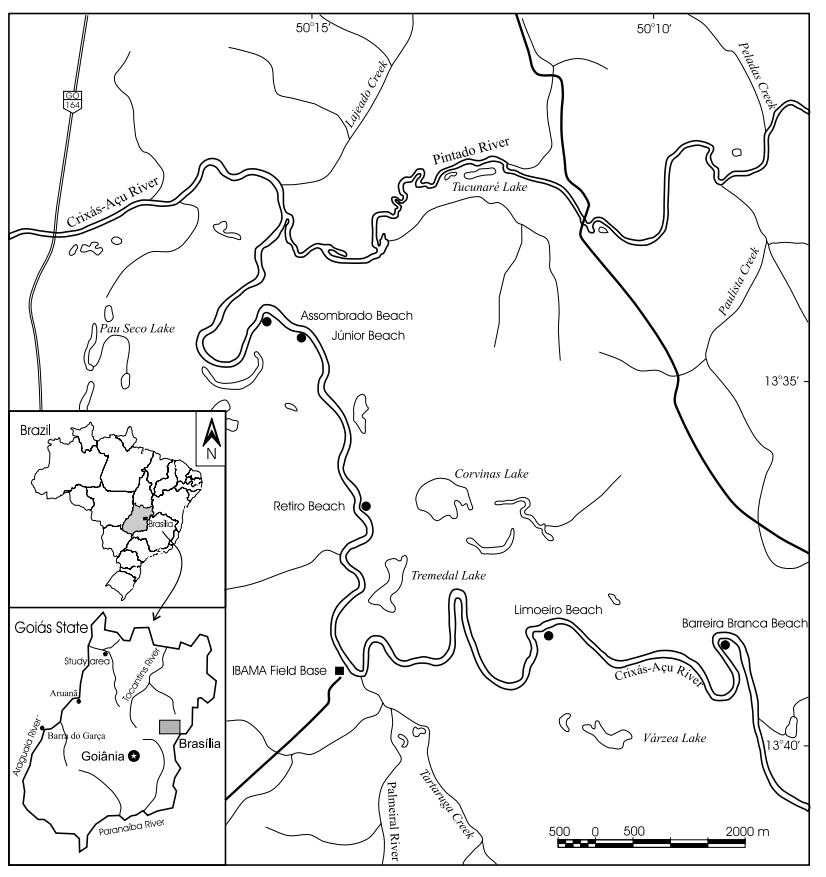

Figure 2 - Localization map of the studied area, highlighting the beaches with greater concentration of the giant Amazon river turtle nests in the nesting season of 2000 .

Table 1 - Granulometric fractions used in the analysis of five sediments samples collected in the nests of the giant Amazon river turtle. Dimensions are given in $\mathrm{mm}$.

\begin{tabular}{llllllll}
\hline \multirow{2}{*}{ Fraction } & \multirow{2}{*}{ Pebble } & Gravel & \multicolumn{4}{c}{ Sand } \\
\cline { 3 - 7 } & & & Very coarse & Coarse & Medium & Fine & Very fine \\
\hline Dimension & $>4$ & $4-2$ & $2-1$ & $1-0,5$ & $0,5-0,25$ & $0,25-0,125$ & $0,125-0,065$ \\
\hline
\end{tabular}


turtles as nest sites. The river level decrease is slow and gradual, but its rise is rapid and irregular.

During the dry season, the Crixás-Açu River level is so low that, in many points, the river can be crossed on foot. The exposure of sandy bars within the channels causes the water to reach depths lower than $30 \mathrm{~cm}$ in several places. In this way, the movements of turtle becomes very difficult and they concentrate in the river pools (called "boiadouros"), safe from their main natural predator, the jaguar (Panthera onca).

\section{GRAIN SIZE ANALYSIS}

The point bars, bars and river banks are formed by sediments with several grain size fractions. The riverbanks are formed by mudstone, sandstone and conglomerate. The grain size fractions of bars and point bars are mud (clay and silt), sand and pebbles.

The results from granulometric analysis of five samples collected along the turtle nesting areas in five beaches show that the sediments concentrate primarily in the sandy fractions (Table 2). The point bars are constituted by sediments classified as coarse sand, with substantial contributions from sand classified as fine to very coarse. The mud volume is very low, less than $0.2 \%$. The Assombrado Beach had the coarsest sediments and the Limoeiro and Barreira Branca beaches had the finest.

\section{DISTRIBUTION OF NESTS ALONG THE BEACHES}

Almost all of the giant Amazon river turtle nesting occurred between 20-30 September 2000. A great number of the turtles laid in two or three days and their nest concentration made the nest separation and counting impossible. The greatest nesting period coincided with the decrease of the Crixás-Açu River level, which happened after a small rise of $26 \mathrm{~cm}$, registered during the first two weeks of September (Fig. 3).

Since each of the five studied beaches present peculiar geological characteristics and a differentiated nest pattern distribution, they will be described separately.

Junior Beach: It is a point bar with low nesting concentrations where only 23 turtle nests were registered (Fig. 4). The nests were located at a maximum height that varied from 183 to 207 cm above the Crixás-Açu River level, on 25 October, which was the day of the lowest channel water level. The well-developed bordering riparian forest constitutes the vegetational cover in the internal side of the meander, which shades the nests that are close to the forest.

The low nesting concentration on this beach is associated with the dimensions and positioning of "boiadouro" (deep pool) and to its geomorphological and sedimentological characteristics. The external border of the point bar near the upstream center area (Fig. 1) is shallow and the water flow is strong and rapid making it difficult for the turtles to move. A small "boiadouro" is located near the downstream part of the beach. It is separated from the point bar by a steep lee face of a great dune that migrates towards the "boiadouro". During the period in which the river is shallower, the river flow causes the erosion of the dune lee side, which makes the boundary between the beach and the "boiadouro" even more abrupt. At this place, exit for the turtle to the beach becomes very difficult, almost impossible. The central part of the point bar presents ramp-shaped morphology with little inclination. At this point, the river presents a water volume which permits the turtle to circulate along the channel. At this juncture, the turtle can easily climb to the highest points

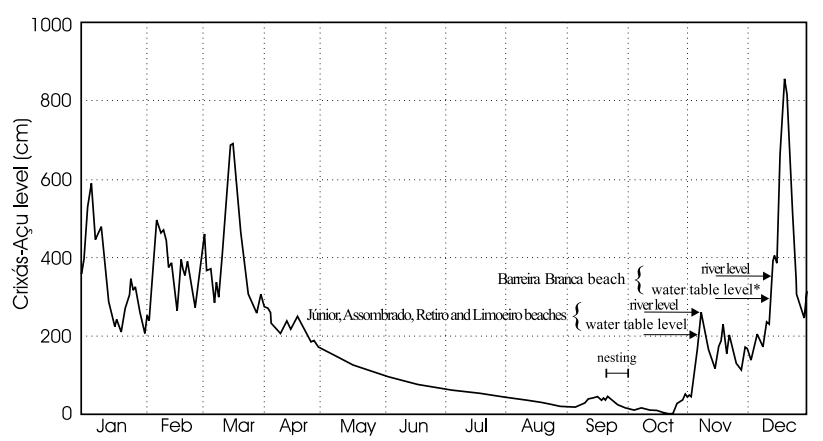

Figure 3 - Variation of the level of the Crixás-Açu River and nesting period in 2000. On October $23^{\text {rd }}$ and $25^{\text {th }}$ the lowest quotas of the year were registered. The greater laying happened between September $20^{\text {th }}$ and $30^{\text {th }}$. The nesting period coincides with the falling of the river level, after a small rising of $26 \mathrm{~cm}$ registered in September. The arrows indicate the river quota and the height of the water table in which the flooding of the nest areas in the point bar happens. The pluviometric data were made available by the Agência Nacional de Energia Elétrica (ANEEL - National Electric Energy Agency) and originated from the Crixás-Açu Station, situated at 4957'05' $W$ and $13^{\circ} 53^{\prime} 55^{\prime \prime} \mathrm{S}$. * Water table level means the water table level in which the clutches are drowning.

Table 2 - Grain size mean (\%) of the nest placement areas of the giant Amazon river turtle in the Crixás-Açu River.

\begin{tabular}{|c|c|c|c|c|c|c|c|c|}
\hline \multirow{2}{*}{ Fraction } & \multirow{2}{*}{ Pebble } & \multirow{2}{*}{ Gravel } & \multicolumn{5}{|c|}{ Sand } & \multirow{2}{*}{ Mud } \\
\hline & & & Very coarse & Coarse & Medium & Fine & Very fine & \\
\hline Júnior & 0,74 & 1,48 & 3,70 & 53,86 & 35,57 & 4,42 & 0,23 & 0,00 \\
\hline Assombrado & 7,61 & 9,30 & 24,42 & 47,49 & 10,08 & 0,60 & 0,35 & 0,16 \\
\hline Barreira Branca & 0,08 & 0,13 & 3,47 & 48,62 & 44,34 & 3,20 & 0,14 & 0,02 \\
\hline Limoeiro & 0,04 & 1,15 & 6,54 & 31,03 & 46,83 & 13,30 & 1,07 & 0,04 \\
\hline
\end{tabular}


of the beach. However, the local pebbly and gross substrate is not compatible for digging nests.

The few registered nests on the Júnior Beach are situated in the central part of the point bar but not at the highest part that was very close to the forest. Nests labeled 34 and 35 were situated in a sunny place almost all day long, but the height relative to the river level was lower, since the place is a secondary channel that cuts through the point bar. On 8 November, the point bar was completely inundated, flooding all the nests and killing all the hatchlings and embryos.

Assombrado Beach: In the year of 2000, a great concentration of giant Amazon river turtle nests along the Araguaia and Crixás-Açu rivers occurred at this point bar (Fig. 5). In a small area of approximately $1750 \mathrm{~m}^{2}(35 \times 50 \mathrm{~m})$, near 500 nests - laid between 22-29 September. The height of the nest surface was from 180 to $213 \mathrm{~cm}$ and as on the Júnior Beach, they were situated below the mean height observed on the other three beaches. Nest counting was not an easy task, since the nests were overlaid. The nest count estimated by IBAMA field agents was based on the nest marks and on the tracks left by the turtles.

The beach is relatively plain, without any dunes. As a consequence there is not the amalgamation of deposits, which could generate topographical levels and a greater environment complexity and diversity. The beach morphology is ramp-like, spotted by a margin with low angle of inclination that connects the highest part of the beach to the "boiadouro".

The geological characteristics of the beach are not adequate for nesting since there is a sandy-silt layer as thick as $20 \mathrm{~cm}$, which covers the entire point bar and makes digging nests difficult. On the other hand, the beach has a "boiadouro" nearby, which permits turtle concentration during the nesting season. This is the determinant feature for high nesting concentration in the Assombrado Beach. The river level was very low in 2000 making transit along the river difficult for the turtles. The nests were flooded on 8 November, before hatching.

Retiro Beach: It is a point bar that is $500 \mathrm{~m}$ long and $90 \mathrm{~m}$ wide. The sandy deposits are more complex. The density of the giant Amazon river turtle nest concentration is high, almost 250 clutches in an area of $4500 \mathrm{~m}^{2}$. The presence of several topographical forms, dunes and flat areas, influenced the nest placement. The presence of a "boiadouro" in front of the beach, access channels and adequate bank topography make access to the nesting site easy for the turtle. Nest distribution is not

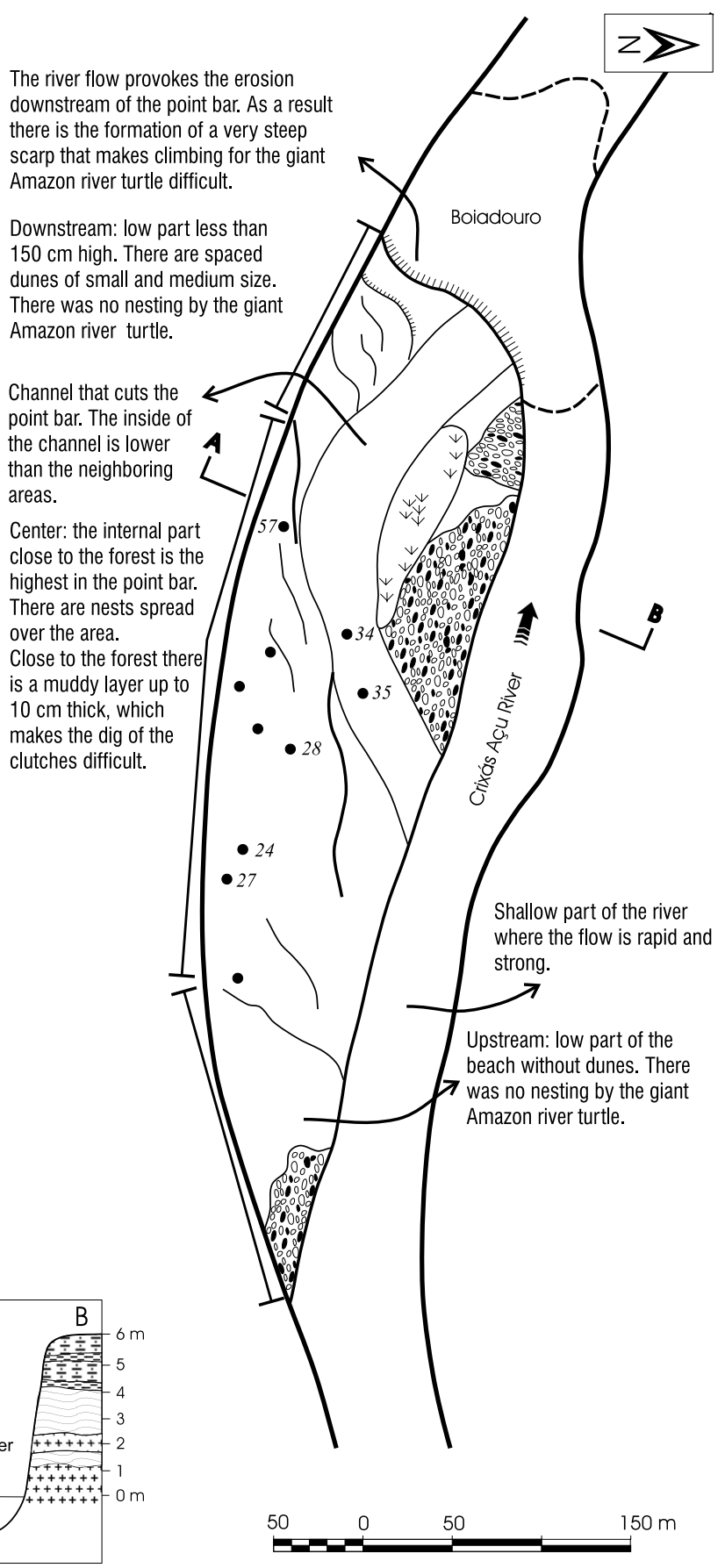

Figure 4 - Morphology of the Júnior beach and distribution of the giant Amazon river turtle nests. The cutaway diagram highlights the tertiary-quaternary conglomeratic deposits, which after being eroded, furnish material to the residual pebbly deposits. 
homogeneous. A lower nest concentration occurred in the places shaded by shrubby vegetation. There the height of the beach is lower than to $2 \mathrm{~m}$ (Fig. 6).

Two platforms characterize the Retiro Beach. The highest platform, between 236 and $260 \mathrm{~cm}$ in height, where the turtle nests, can be subdivided in two portions: one upstream that concentrates the nests, without vegetation and close to the "boiadouro"; the other downstream, which in spite of being high with a sandy substrate does not have nests, since it is covered by bushes and the "boiadouro" is not directly connected to the beach. At this last portion, a very abrupt dune blocks the high

High density of the giant Amazon river turtle nests with almost 500 clutches (situated in the hatched part). There is a superposition of the nests and it is difficult to distinguish them.

This is relatively plain without dunes and high platforms. This ramp-like point bar and the greater heights are in the downstream portion.

A fine clay layer with a thickness of up to $20 \mathrm{~cm}$ covers the entire beach and in the nesting site it had to be removed to reach the sandy substratum

Low site, insufficiently high to have the giant Amazon river turtle nests. The presence of residual pebbly deposits is not verified.
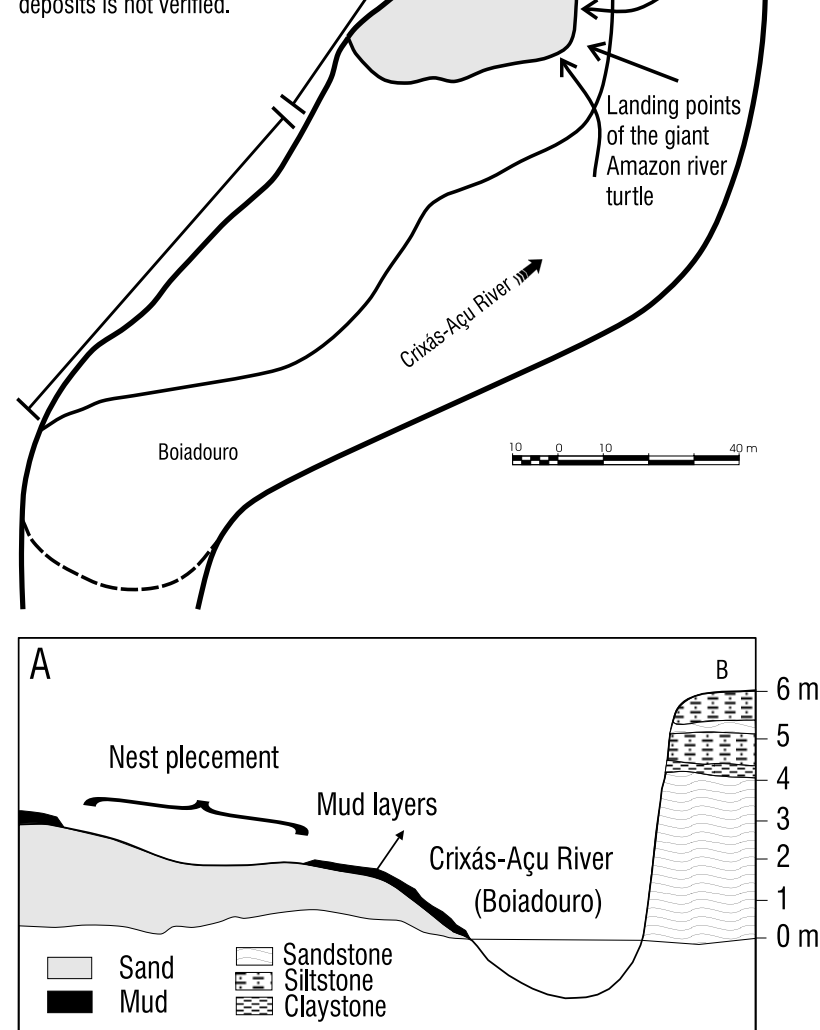

Figure 5 - Morphology of the Assombrado beach and the distribution of giant Amazon river turtle nests. The cutaway diagram highlights the pelitic layer, which covers the sandy deposits of the nest site. part of the beach, making the access for the giant turtle difficult. The area used for nesting by the turtle was flooded on 8 November.

Limoeiro Beach: It is a point bar $575 \mathrm{~m}$ long and $70 \mathrm{~m}$ wide, where jaguars prey on the turtles intensely. Seventeen giant Amazon river turtles were found with marks of been killed by jaguars during the 2000 nesting season. The nest area is almost $4000 \mathrm{~m}^{2}$ and the number of turtle nests is estimated at about 200 to 250 (Fig. 7).

The nesting area was altered by the rising water during the last flood period. As a result, the portion where the turtle nests

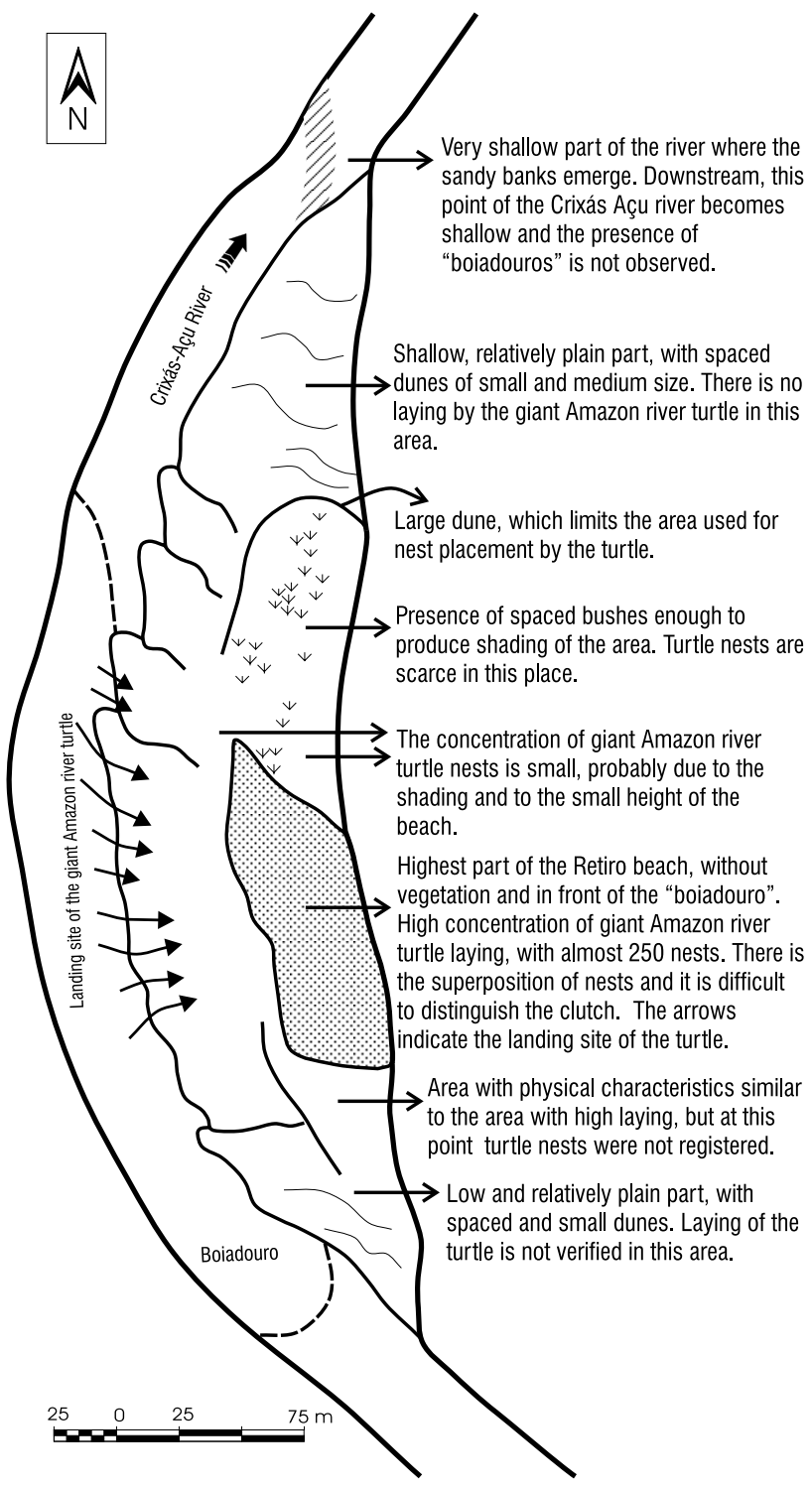

Figure 6 - Morphology of the Retiro beach and distribution of the giant Amazon river turtle nests. 
were concentrated was approximately $310 \mathrm{~cm}$ higher relative to the remaining point bar. Upstream there are pebbly deposits originating from the erosion of ancient conglomeratic deposits, making this point unfit for nesting.

The "boiadouro" is limited upstream by a dune that partially emerges during the dry period, determining the beginning of an area where the water flow is rapid and the river substratum becomes gravelly and shallow, which makes the movement of the giant turtle difficult. Downstream, the "boiadouro" is limited by shallow and gravelly bars. The access to the nesting place is made by a ramp with a slightly inclined slope.

In spite of the point bar not having been totally flooded by the rising water level on 8 November, the eggs did not hatch on this beach. The clutch base of the turtle is about $60 \mathrm{~cm}$ deep and since the maximum height of laying in this beach was of $310 \mathrm{~cm}$, the height of the nest base was located about $250 \mathrm{~cm}$ of the Crixás-Açu River level. Since the swell of rising water on 8 November reached $262 \mathrm{~cm}$, all the nests had at least their lower part submerged. The nests sites on the entire Limoeiro Beach

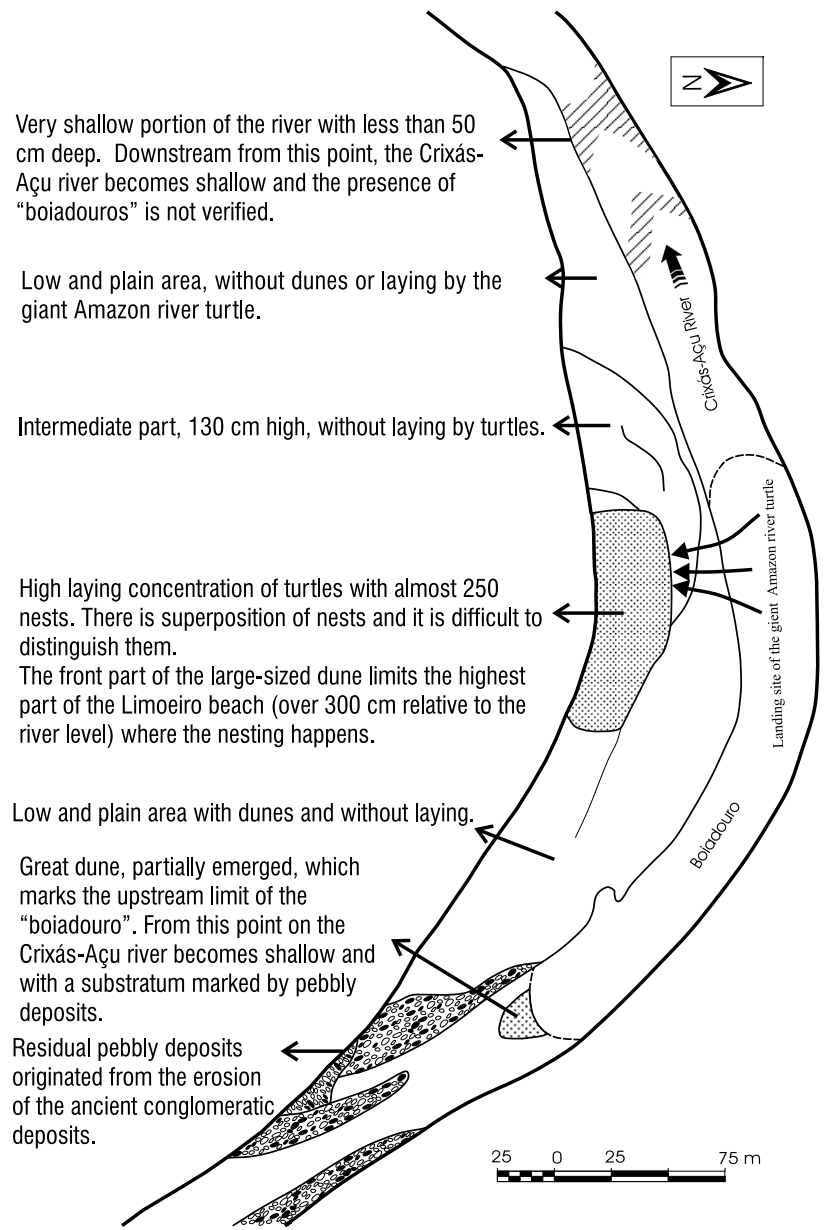

Figure 7 - Morphology of the Limoeiro beach and distribution of the giant Amazon river turtle nests. was completely inundated on 13 December.

Barreira Branca Beach: It is a point bar about $550 \mathrm{~m}$ long and $75 \mathrm{~m}$ wide. The highest point of the nesting area is located $380 \mathrm{~cm}$ higher than the river level. Favorable nesting conditions appeared only in the highest parts of the beach. It is estimated that 250 giant Amazon river turtles laid in this point bar (Fig. 8). The "boiadouro" extends the width of the channel in front of the beach and the turtle aggregate prior to nesting is downstream, where the water flow is lower and the river is wider and deeper.

Sandy and silt deposits characterize the Crixás-Açu River bank in the right margin, opposite to Barreira Branca Beach. At its base there are conglomerates with gravel of up to $20 \mathrm{~cm}$ in size, which after erosion and removal of the finest fraction compose the residual gravelly deposits. In the specific case of Barreira Branca Beach, the location of the residual gravelly deposits does not make turtle nesting impracticable since the concentration is in low topographical portions, which are avoided by the turtle.

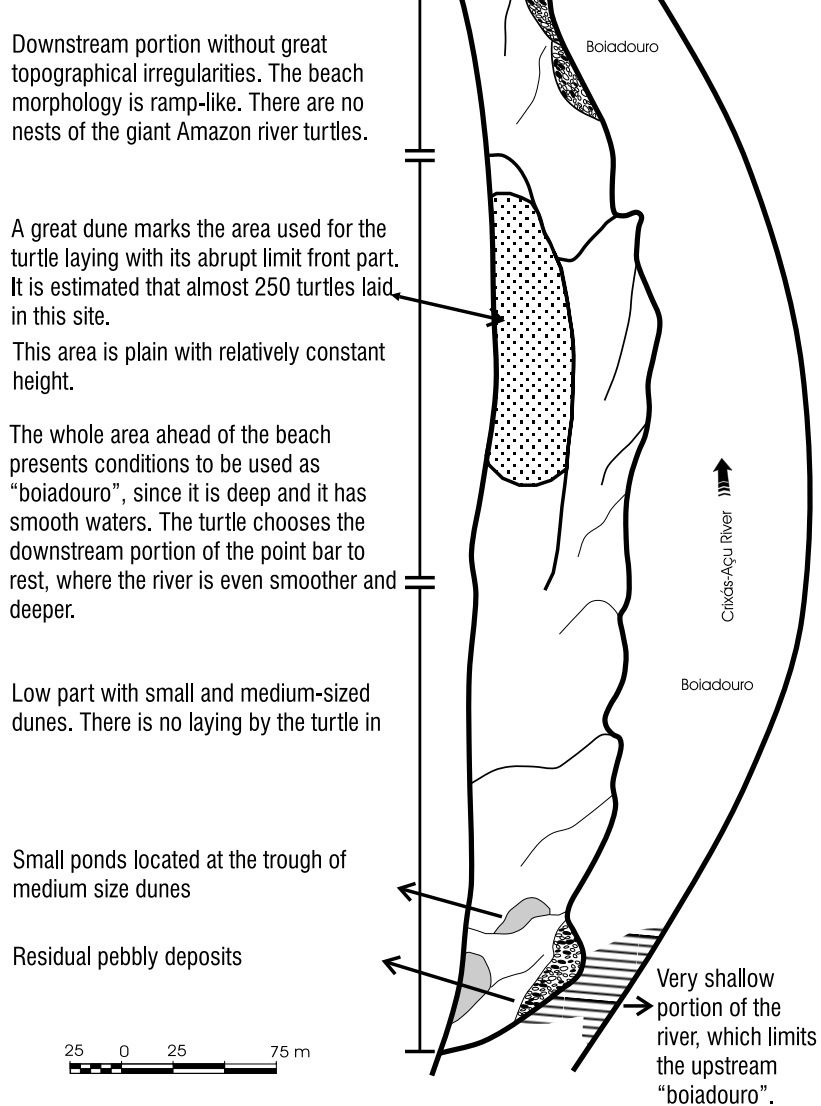

Figure 8 - Morphology of the Barreira Branca beach and distribution of the giant Amazon river turtle nests. 
In the highest sites of the point bar, the turtle clutch bases were located at least $60 \mathrm{~cm}$ higher than the water table on 8 November, when the rising water occurred. Thus, it may have been possible that some nests hatched. Unfortunately, after the rising water on 8 November, RAN/IBAMA suspended the reproductive season monitoring activities, as they had concluded that all the nests were lost. The nest site was completely flooded only on 14 December.

\section{DISCUSSION}

In the area of the Crixas-Açu River monitored by IBAMA, five beaches with a high nesting concentration were studied, where about 1700 P. expansa nested in 2000. The morphological characteristics of the nesting beaches are similar, allowing for a diagnostic of geomorphologic and sedimentological patterns of the sites chosen by the turtles for nesting. As a general characteristic, all the sites with high concentration nests can be classified as point bars and the geological complexity of these bars will depend mainly on their dimensions. Smaller bars present a simpler arrangement but usually without the platform originated by the dunes migration and superposition. The point bars with smaller dimensions, such as Assombrado Beach, present a ramp surface without significant unevenness. The scarce dunes found upstream or downstream are usually lower than $50 \mathrm{~cm}$ in high.

The larger point bars, such as the Limoeiro and Retiro beaches, show a more complex arrangement, where one can verify the amalgamation of several dunes more than $100 \mathrm{~cm}$ high, causing different morphological levels. The boundaries of the dunes mark the morphological differences of the sites chosen by the giant Amazon river turtles for nesting. The absence of vegetational cover and the presence small dunes, and their loosely packed sediments suggest that the higher point bars' deposits are reworked by annual floods.

The substratum of the turtle nests is characterized by poorly selected sediments concentrated in the sandy fraction (Table 2). The grain size of the sediments could be one of the criteria for the turtle selecting nesting areas in the Crixás-Açu River. The turtles always nested in the high beach areas, as long as the sediments are formed by sand. In the Júnior Beach (Fig. 3), the high places covered by pebbles did not allow the digging of nests, and the turtles laid in the sandy sites, which were lower. In the Assombrado Beach, the $20 \mathrm{~cm}$ mud layer had to be removed in order to dig the nests. This fact, combined with the high number of nests, increased nest overlap, since nest digging became easier in the sites where the mud layer had already been removed by giant Amazon river turtles nesting previously.

The presence of residual gravel deposits is controlled by the regional geological structure. There is a discrepancy between the gravel sizes, usually over $15 \mathrm{~cm}$, and the energy of the Crixás-
Açu River, indicating that the present water flow cannot transport clasts with these dimensions. The present river course cuts Tertiary-Quaternary sedimentary deposits of the Bananal Formation (Bayer et al., 2001; Latrubesse et al., 1999; Mamede et al., 1981). The presence of conglomeratic deposits is frequent, and these can extend for hundreds of meters and can be up to $150 \mathrm{~cm}$ thick. The conglomeratic levels have an interlayer with sandy and silt-sandy deposits. The erosion of the conglomeratic deposits causes the removal of the finer clasts by the water flow. In this way, only the large clast fraction, such as gravel and pebble, remains in the place, and when they are transported they go for small distances, generating residual gravelly deposits. Depending upon the original Tertiary-Quaternary conglomeratic deposits, these deposits may occupy significant portions in the point bars as it happens in the case of the Júnior Beach, or small sections, as exemplified in the Limoeiro and Barreira Branca beaches. During the lowing of the river level, a silt-sandy layer up to $20 \mathrm{~cm}$ thick may accumulate over the sandy deposits. In some sites this layer is thin and can be easily removed by turtles or desiccated by rain and wind. In the Assombrado Beach, however, a relatively uniform layer more than $10 \mathrm{~cm}$ thick covers entire extension of the point bar. The area used for nesting by 500 turtles had to be dug on the silt-sandy layer in order to reach an adequate substratum for the nests. Therefore, the digging of the superficial muddy layer demands an extra effort by the turtle, since the material becomes dry and very cohesive when dehydrated after being exposed to the sun. The high concentration of turtles in this site and the laying space restrictions contribute to a high nesting concentration with a great number of overlapping nests.

The maximum height of the nesting sites varied along the beaches and was over $200 \mathrm{~cm}$ on average, relative to the CrixásAçu River in 2000. These areas are located in the point bars' intermediate part, where the migration and amalgamation of the sedimentary deposits generate morphological levels, which provide good nesting conditions for the turtle. The height of the nest sites was decisive for the hatchling success. The nests located on the Júnior, Assombrado, Retiro and Limoeiro beaches were flooded due to the rise of the Crixás-Açu River on 8 November. Some areas of the Barreira Branca Beach, located in the highest places, had only been completely flooded as of 14 December, what probably allowed for the hatching and the emergence of the hatchling from some nests.

Sudden rising of the water level is usual in the Amazonian rivers and the consequences on the hatchling success depend on the rising water magnitude and the height of the nest sites. Pezzuti \& Vogt (1999) mentioned that the greatest concentration of nests of P. sextuberculata (75.6\%), in the Japurá River in Brazil happens on the highest sites of the beaches. Mitchell \& Quiñones (1994) found a positive correlation between the beach height and the number of nests of $P$. unifilis 
in Peru. Hildebrand et al. (1988) concluded that the loss of nests of the giant Amazon river turtle in Caquetá River in Colombia, was due to the rising of the water oscillating from $0 \%$ to $100 \%$. Soini (1995) has showed a similar phenomenon in the Pacaya-Samiria national reserve in Peru, where the rising of the water inundates from $1 \%$ to $100 \%$ of the $P$. expansa, $P$. unifilis e P. sextuberculata nests.

In the study area various other point bars occur that are not used by the giant Amazon river turtle due to, at least, four reasons: a) inexistence of "boiadouros" near the beaches, which makes aggregation in shallows, prior to landing, impossible, as described by Vanzolini (1967); b) insufficient height of the point bars, which are lower than $150 \mathrm{~cm}$; c) absence of safe connection among the pools of the river ("boiadouros"), which makes the turtles moving to new nesting areas difficult for the turtles and d) inadequate substratum formed by gravel size sediments or mud sediments. All these reasons - acting individually or together - make the nesting difficult for the giant Amazon river turtle in almost all the point bars of the Crixás-Açu River. Only a few beaches fulfill the necessary nesting requirements, which allied to the turtle's gregarious habits (Alho \& Padua, 1982; Vanzolini, 1967), causes high concentration of nests in small areas.

The high nest concentration, and their consequent superposition in very small areas, is due to the lack of wider suitable areas and of a greater geological diversity in the point bars. The few point bars over $200 \mathrm{~cm}$ high that present associated "boiadouros" are widely used by the turtle as nesting site. This characteristic directs the protection and monitoring of the turtle in the reproductive season to the small areas with large number of nests. On the other hand, sudden rising water level, such as the one that happened on November $8^{\text {th }}$, can affect survivorship, as was verified in 2000. This happens because the nesting sites are high enough to permit great variations of the river on water table levels to occur without damage to the eggs. The concentration of nests in restricted areas can also cause the incubation of a great hatchling number in similar thermal environments, which could induce production sex ratio bias (Bull, 1980; Bull, 1985; Vogt \& Bull, 1984). Greater environment diversity contributes to the distinct boundary conditions of the nests that could influence the embyogenesis and the sexual determination in different ways (Alho et al., 1985; Packard et al., 1987). Studies on the hatchling sex ratio generated in these environments will be necessary in order to determine their influence.

The analysis of the giant Amazon river turtle nest sites in the Crixás-Açu River shows the influence of the geological aspects in the nesting areas. The grain size of substratum, the presence of "boiadouros" and high beach areas (over $200 \mathrm{~cm}$ ) are important aspects for local high nest concentration. The same geological aspects as those listed to Crixás-Açu River are also important for other giant Amazon river turtle nesting areas such as in the
Araguaia River, in the state of Goiás, and in the Javaés River, in the state of Tocantins as shown by Ferreira Junior (2003) and Ferreira Júnior \& Castro $(2003,2005)$.

\section{ACKNOWLEDGEMENTS}

This paper is part of the Ph. D. Thesis of Paulo Dias Ferreira Júnior of the Departmento de Geologia of the Universidade Federal de Ouro Preto (UFOP), supported by a CAPES fellowship, to whom the author would like to thank. UFOP and IBAMA provided the financial support and infrastructure necessary for the field work. The authors would like to thank Yeda Bataus, Vera Lúcia, Paulo Saldanha and IBAMA agents, for their support in the field.

\section{LITERATURE CITED}

Alho, C.J.R.; Pádua, L.F.M. 1982. Sincronia entre o regime de vazante do rio e o comportamento de nidificação da tartaruga da Amazônia Podocnemis expansa (Testudinata: Pelomedusidae). Acta Amazonica, 12(2): 323-326.

Alho, C.J.R.; Danni, T.M.S.; Pádua, L.F.M. 1985. Temperaturedependent sex determination in Podocnemis expansa (Testudinata: Pelomedusidae). Biotropica, 17(1): 75-78.

Ashworth, P.J.; Best, J.L.; Roden, J.E.; Bristow, C.S.; Klaassen, G.J. 2000 Morphological evolution and dynamics of a large, sand braid-bar, Jamuna River, Bangladesh. Sedimentology, 47(3): 533 555.

Bayer, M.; Latrubesse, E.; Stevaux, J. 2001. Quaternário da planície aluvial do rio Araguaia entre Registro e Cocalinho - MT. In: VIII Congresso da Associação Brasileira de Estudos do Quaternário, Campinas, São Paulo. Anais, p.279-283.

Bragg, W.K.; Fawcett, J.D.; Bragg, T.B. 2000. Nest-site selection in two eublepharid gecko species with temperature-dependent sex determination and one with genotypic sex determination. Biol. J. Linn. Soc., 69: 319-332.

Bull, J.J. 1980. Sex determination in reptiles. Q. Rev. Biol., 53(1): 320.

Bull, J.J. 1985. Sex ratio and nest temperature in turtles: comparing field and laboratory data. Ecology, 66(4): 1115-1122.

Bull, J.J.; Vogt, R.C. 1979. Temperature-dependent sex determination in turtles. Science, 206(7): 1186-1188.

Charnier, M. 1966. Action de la temperature sur la sex-ratio chez l'embryon d'Agamma agama (Agamidae, Lacertilien). Soc. Biol. Ouest Afric., 160: 620-622.

Ernst, C.H.; Barbour, R. W. 1989. Turtles of the World. Smithsonian Institution Press, Washington, USA. 313pp.

Ewert, M.A.; Etchberger, C.R.; Nelson, C.E. 2004. Turtle sexdetermining modes and TSD patterns, and some TSD pattern correlates. In Valenzuela, N.; Lance V.A. (eds.). TemperatureDependent Sex Determination in Vertebrates. Smithsonian Books, Washington, USA. p.21-33.

Ferguson, M.W.J.; Joanen, T. 1989. Temperature of egg incubation determines sex in Alligator mississippiensis. Nature, 296: 850-853. 
Ferreira Júnior, P.D. 2003. Influência dos processos sedimentológicos e geomorfológicos na escolha das áreas de nidificação de Podocnemis expansa (tartaruga-da-amazônia) e Podocnemis unifilis (tracajá) na bacia do rio Araguaia. Contribuiçôes às Ciências da Terra, Série D, Volume 3, (Tese de Doutorado, Departamento de Geologia, Universidade Federal de Ouro Preto, Ouro Preto, Minas Gerais) 296pp.

Ferreira Júnior, P.D.; Castro, P.T.A. 2003. Geological control of Podocnemis expansa and Podocnemis unifilis nesting areas in Rio Javaés, Bananal Island, Brazil. Acta Amazonica, 33(3): 445-468.

Ferreira Júnior, P.D.; Castro, P.T.A. 2005. Nest placement of the giant Amazon river turtle, Podocnemis expansa, in the Araguaia River, Goiás State, Brazil. Ambio, 34(3): 212-217.

Folk, R.L. 1974. Petrology of Sedimentary Rocks. Hemphill Publication, Austin, USA. 182pp.

Harlow, P.S. 2004. Temperature-dependent sex determination in lizards. In Valenzuela, N.; Lance V.A. (eds.). TemperatureDependent Sex Determination in Vertebrates. Smithsonian Books, Washington, USA. p.42-53.

Hildebrand, P.; Saenz, C.; Pehuela, M.C.; Caro, C. 1988. Biologia reproductiva y manejo de la tortuga Charapa (Podocnmeis expansa) en el bajo rio Caqueta. Colomb. Amazónica, 3(1): 89-102.

IBAMA - Instituto Brasileiro do Meio Ambiente e dos Recursos Naturais Renováveis 1989. Projeto Quelônios da Amazônia, 10 anos. IBAMA, Brasília. 119pp.

Latrubesse, E.; Stevaux, J.C.; Bayer, M.; Prado, R. 1999. The AraguaiaTocantins fluvial basin. Bol. Goiano Geogr., 19(1): 120-127. (Volume especial).

Mamede, L.; Nascimento, J.L.S.; Santos, L.M. 1981. Projeto RADAMBRASIL, Levantamentos de Recursos Naturais, Folha SD.25 Goiânia, Geomorfologia, Rio de Janeiro, MME/Secretaria Geral, 25: 301-376.
Mitchell, C.; Quiñones, L. 1994. Manejo y conservacion de la taricaya (Podocnemis unifilis) en la Reserva de Biofera del Manu, Madre de Dios. Bol. Lima, 16: 425-436.

Packard, G.C.; Packard, M.J.; Miller, K.; Boardman, T.J 1987. Influence of moisture, temperature, and substrate on snapping turtle eggs and embryos. Ecology, 68(4): 983-993.

Pezzuti, J.C.B.; Vogt, R. 1999. Nesting ecology of Podocnemis sextuberculata (Testudines, Pelomedusidae) in the Japurá River, Amazonas, Brazil. Chel. Conserv. Biol., 3(3): 419-424.

Pieau, C. 1971. Sur la proportion sexuelle chez les embryons de deux chéloniens (Testudo graeca L. et Emys orbicularis L.) issus d'oefs incubés artificiellement. C. R. Hebd. Séanc. Acd. Sci Paris, 272D: 3071-3074.

Pritchard, P.C.H.; Trebbau, P. 1984. The Turtles of Venezuela. Society for the Study of Amphibians and Reptiles, Caracas, Venezuela. 403pp.

Soini, P. 1995. Investigaciones en la Estación Biológica Cahuana. Reporte Pacaya-Samiria, Universidad Nacional Agraria La Molina, La Molina, Peru. 435pp.

Vanzolini, P.E. 1967. Notes on the nesting behaviour of Podocnemis expansa in the Amazon Valley (Testudines, Pelomedusidae). Papéis Avulsos de Zoologia, 20: 191-215.

Vogt, R.C.; Bull, J. 1984. Ecology of hatchling sex ratio in map turtle. Ecology, 65(2): 582-587.

Vogt, R.C.; Bull, J. 1982. Temperature controlled sex-determination in turtles: ecological and behavioral aspects. Herpetologica, 38(1): 156-164.

Recebido em 25/08/2004 Aceito em 10/02/2006 